\title{
Islamic Human Rights Discourse and Hermeneutics of Continuity
}

\author{
Arnold Yasin Mol \\ PhD candidate at Leiden University, researcher at the Institute for the \\ Revival of Traditional Islamic Sciences (IRTIS.org.uk). \\ aymol@irtis.org.uk
}

\begin{abstract}
After World War II the United Nations developed new international law constructs in cooperation with the majority of the world's nations, which were mainly based on a Western hermeneutic of rights. This international humanistic project provided new anthropological constructs which were seen as compatible or non-compatible, by Muslims or non-Muslims, with Islam. When analyzing these discussions on Islam and human rights discourse into a typology they can provide insights where compatibility and non-compatibility lies, and where possible reinterpretation is needed. Within the typology, two forms of discourses can be discerned: Islamic human rights discourse as the internal Muslim discourse on human rights and the external 'Islam and human rights' discourse which emerged together with the modern human rights regimes. By analyzing the different elements of what constitutes Islam and human rights discourse we can derive new understandings and strategies in how to engage a modern Islamic human rights discourse and constitute an Islamic science of human rights ( $\mathrm{ilm}$ al-ḥuqūq) which provides a hermeneutics of continuity between Islam and modern human rights and overcomes both apologetics and othering.
\end{abstract}

\section{Keywords}

Islam and human rights - huqū̄q Allāh wa-huqūq al-ibād - Islamic reform - Islamic jurisprudence - Islam and modernity 


\section{Introduction}

After World War II the United Nations developed new international law constructs in cooperation with the majority of the world's nations, which were mainly based on a Western hermeneutic of rights. This international humanistic project provided new anthropological constructs which were seen as compatible or non-compatible, by Muslims or non-Muslims, with Islam. When analyzing these discussions on Islam and human rights discourse into a typology they can provide insights where compatibility and non-compatibility lies, and where possible reinterpretation is needed. To move beyond this seeming dichotomy between Islam and human rights we must first determine whether a viable discourse on Islam and human rights even exists, and if so, how it approaches both Islam and human rights. Through this analysis we hope to formulate an effective strategy for a viable and thick descriptive Islam and human rights discourse. As this is only an exploratory article we cannot analyze the full existing discourse on Islam and human rights, but we only need to construct a typology descriptive enough to determine a strategy. We therefore determine the state of the discourse by analyzing works directly focused on Islam and human rights. Constructing a typology of Islam and human rights discourse is, of course, itself a thin description, but basing ourselves on several monographs on the subject might help show us how Islam and human rights are defined, measured, and by what it is represented. Islam and human rights revolve around several questions: Is a form of compatibility between Islam and modern human rights possible? If so, based on what premises or comparative material? Has a satisfactory form of compatibility been achieved yet? Have Muslims simply incorporated human rights discourse ('Islamization of human rights') or engaged ('synthesis/compatibility') with it? Another important question is that of universalism of either human rights or Islam itself, or which element of both can be called universal or not. Claiming something has a universal or relative status is by itself a claim from power, as the universal will always be used as the norm for the relative. To construct a small but coherent typology ${ }^{1}$ we have selected works that share a similar language and time-period: the post-9/11 English works by three Muslim authors (Baderin,

1 The typology presented here is a small sample of a larger research on Islam and human rights typology, parts of which I presented at the 2019 symposium Islamic Reformation and Tajdid organised by the Islamic University of Applied Sciences Rotterdam (IUR) and Hamad Bin Khalifa University ( $\mathrm{HBKU}$ ), and which will be published in an upcoming symposium edition of the Journal of Rotterdam Islamic and Social Sciences (JRISS). For the symposium, see: www.iur.nl/2019/05/02/islamic-reformation-and-tajdid/. 
Moussalli, and Sachedina) and one non-Muslim author (Mayer). ${ }^{2}$ By assessing the different elements of what constitutes 'Islam(ic law)' and 'human rights discourse' we can derive new understandings and strategies in how to engage with a modern Islamic human rights discourse which overcomes both apologetics and othering.

\section{2 \\ The Question of Islam and Human Rights}

The question on how Muslims governed themselves has, apart from Muslims themselves, also been a central concern of those who viewed them as the Other. ${ }^{3}$ We see this especially in the development of Western discourse concerning Islam which centered both around the scriptural and creedal differences between Islam and Christianity, and the slow construction of a cultural dichotomy between the 'civilized west' and the 'barbaric east' (Bijlefeld 1959, 56-73, 148-165, 205-207; Curtis 2009, 31-37; Berger 2014, 184-186). With the 2oth century decline of the centrality of Christianity within the West, the cultural discourse has come to the foreground, shifting Western engagement to Islam from a clash of religion to a clash of civilization. ${ }^{4}$ After the Iranian revolution of 1979 and the later collapse of the communist states a renewed academic focus on Muslim views on Sharía, governance and international law formed in relation to foreign policy and international relations. But it was after $9 / 11$ and the beginning of the 'war on terror' that this focus extended beyond the academic field. Scholars and non-professionals, Muslims and non-Muslims alike, wrote to explain, explore, incriminate or apply apologetics towards Islam, placed jihād and Sharî́a versus Christianity, the West, secularism, democracy, and international human rights law. A common aspect of these writings is that they rarely explain these concepts, but instead seemingly work from premises that are assumed as a given, whereby Islam and human rights has become a central subject of 'undefined-premises' works. ${ }^{5}$ Just as William Cavanaugh observed the dichotomy of 'religious violence $=$ barbaric' versus 'secular violence

2 We therefore, for now, have ignored important multi-lingual monographs such as Bin Bayyah 2006; Al-Nabrāwiyya 2008; Al-Ṭāhūn 2013; Al-Marzouqi 2000; Al-Jabri 2008; Kamali's Fundamental Rights And Liberties In Islam Series 1999, 2002a, 2002b, 2007, 2008, 2011a, 2011b; and editorials such as Emon et al. 2012; Saeed 2012.

3 On concepts of the Other, othering, and otherization, see Brons 2015.

4 As embodied by the writings of Samuel Huntington and Francis Fukuyama, see: Al-Braizat 2002; Acevedo 2008, 1711-1713; Aysha 2003; Adib-Moghaddam 2011, 1-22ff.

5 "During recent decades a host of publications have seen the light with titles like: 'Islam and X' or 'X in Islam', where $\mathrm{X}$ is typically a concept with a positive connotation, such as democracy, peace, social justice, or women's rights. Titles like 'Islam and Human Rights' and 'Human Rights in Islam' have been particularly popular. Publications with such titles are as a rule 
= civilized' (Cavanaugh 2009, 4). We can observe a similar dichotomy in 'Islam and human rights' discourse as in 'Islam(ic law) = barbaric' versus 'secular/ Western (law) = civilized'. The 'secular/West' is therefore collapsed with 'human rights' as a given, whereby 'human rights' becomes conflated with Western culture and society. ${ }^{6}$ And these conflations and assumptions can have direct effect on policy, as for example in a European court for human rights ruling in 2003 which concluded that Sharita and the European convention of human rights are incompatible (ECHR 2007, 6). Such absolutist claims about historical religious constructs "depend upon a concept of religion as something that retains the same essence over time, retains the same essence across space, and is at least theoretically separable from secular realities" (Cavanaugh 2009, 9). As Christianity represented Western religion, so has secular-liberal democracy and human rights discourse become to represent Western culture. What is labeled as Western is technically seen as modern, and therefore by essence compatible with everything developed within modernity. Islam, and especially 'Shari' $a$ ' or 'Islamic law', is generally considered to be traditional, and therefore lacks this essential compatibility (Masud 2012, 104-105). In the 19th and 2oth century the classical Islamic polity collapsed and was replaced, through internal and external forces, with Western constitutionalism and nationalism. ${ }^{7}$ The constitutionalist movements, beginning with the Ottoman Tanżimāt reforms (1839-1876), ${ }^{8}$ introduced the engagement of Islamic reformist thought with Western law and polity. After the Second World War, the United Nations developed new international law constructs, which were mainly based on Western concepts of personhood and rights (Boot 2017, 1; Griffin 2013, 9-10). This new universal charter of rights (UDHR, 1948) was ratified by the majority of the world's nations, which included the majority of Muslim nations (Mayer 2007, 12; Abiad 2008, 59-62). This international humanistic project introduced new anthropological-juristic constructs, new views on personhood and the legal-political framework needed to sustain this personhood, which had developed beyond its foundations of 18th-19th century liberalism..$^{9}$ Although these new views on personhood conflicted with several traditional concepts of

partisan and indicative of one of two attitudes: they are either incriminating or they are apologetic" (Peters 1999, 5-6).

6 Whereby Christianity in general is seen as having a high or complete compatibility with modern human rights. For Christian human rights discourse, see for example: Moyn 2015.

7 For an overview of Islamism, nationalism and constitutionalism in Muslim countries, see: Grote and Roder 2012.

8 On the Tanzimat, see: Davison 1963; Ardiç 2009, 68-120; Rubin 2006, 25-125, 173-227; Koçak 2010, 233-239; Akgündüz 2011, 213-287.

9 For an analysis on how modern human rights law affects concepts of personhood and identity, see: Marshall 2014. 
personhood, ${ }^{10}$ it was especially Islam which became to be viewed as conflicting or even as non-compatible with post-wwiI human rights discourse. ${ }^{11}$

This perceived non-compatibility generated both incriminating and apologetic discourses which for the majority can be described as thin descriptions or merely superficial as these comparative discourses rarely take into account that the concept of contemporary human rights is very recent and developed out of an earlier liberal philosophy and legal system only applied to free white men and considered slavery as not conflicting with the early liberal concept of rights. Rarely are these foundational texts criticized for their failings in upholding modern human rights concepts as it would be meaningless to criticize these embryonic thoughts for not being completely similar to the later human rights declarations. The same applies to comparing classical Islamic law with modern international human rights in order to establish whether or not it is in conformity with modern human rights standards. These comparative discourses either lead to anachronistic approaches or one whereby the vast heritage of Islamic law is simply replaced by inconsistent quotations from the Qur'ān and Hadìth serving to prove that Islam has always propagated human rights as they are recognized today (Peters 1999, 6).

\section{3}

A Typology of 'Islam and Human Rights' Discourse

To understand the relation between human rights discourse and Islamic law, we first need to assess how human rights and Islam are defined and compared. When analyzing these discussions on Islam and human rights discourse into a typology they can provide insights where compatibility and non-compatibility lies, and where possible renewal, reform, and reinterpretation is needed.

Ann Elizabeth Mayer, in her famous work on this subject (2007), emphasizes that this type of comparative discourse mainly applies a simplistic approach to Islam, which misleads many into thinking that there is an Islamic cultural particularism which shapes all of Muslim thinking and their (semi-)denial of human rights. Her own sources for what represents Islam are modern Islamic human rights declarations or schemes (such as the 'Cairo Declaration'12), and

10 For a discussion on this, see: Stibora 2013, 38-39.

11 There are generally several main 'concerns' which define the claimed non-compatibility: The supremacy of the Sharita above national (i.e., secular) or international human rights law, unequal legal status of women and non-Muslims, and cruel corporal punishments (Otto 2010, 29-33).

On the Cairo Declaration, see: Mayer 2007, 31-33. 
both the positive law and constitutions of several Muslim-majority countries. She accuses these schemes, positive law, and constitutions to be "highly selective" and "less-than-coherent appropriations of Islamic principles" (Mayer 2007, xii). They are, from her viewpoint, failed 'Islamization of knowledge' projects. ${ }^{13}$ She acknowledges that Islam has certain classical values which are compatible with modern human rights discourse, but these are not enough to form a complete Islamic human rights scheme which is also completely compatible with international human rights schemes. In a sense, she claims that Islam by itself is not enough to meet the norm given by international human rights law, nor is it by itself the main obstacle for Muslim countries to achieve that norm. Compatibility is therefore possible, but more as an acceptance by Islam of a higher order of norms (i.e. modern human rights law). Compared to Mayer, the works of Mashood Baderin, Ahmad Moussalli, and Abdulaziz Sachedina provide important counter-observations for our typology.

Baderin, on the other hand, uses a dialectical approach towards Islamic and human rights law, which he views as two universal systems, whereby he asks "to what extent can international human rights law be interpreted in the light of Islamic law and vice versa?" He challenges the premise that observing modern human rights is impossible within an Islamic legal regime (Baderin $2008,5)$. Moussalli also criticizes the non-compatibility position by first of all stating that "modern Islamic thought in general, and today's moderate Islamism in particular, has absorbed and "Islamized" the notions of democracy, pluralism, and human rights. At the religious and ideological level, Islamicly developed doctrines on democracy, pluralism, and human rights constitute a theology of liberation and an epistemological break with the past" (Moussalli 2003, 3, emphasis mine).

The idea of reform has in general resulted in what can be called a hermeneutics of discontinuity, which believes a new Islam has to be constructed to fit modern human rights discourse, thereby ignoring that a hermeneutics of continuity, a meaningful human rights discourse based on Islamic source texts and tradition, can be constructed. ${ }^{14}$ The possibility of such a hermeneutics can be determined by the simple fact that classical Muslim scholars already developed similar schemes in their own contexts. A fact which Moussalli also points

13 On Islamization of knowledge, see: Dzilo 2012, 247-256.

14 The concepts of hermeneutics of continuity and discontinuity is originally used within Catholic discussions on Vatican II in how the council, especially concerning its embrace of modern human rights discourse, represents a break with the Catholic tradition. I have used it here in relation to the Islamic tradition and human rights. For discussion on the hermeneutics and Vatican II, see: Martens 2009, 150-151. 
out: "However, had [Mayer] looked at the original texts of the Qur'ān and the Prophetic Traditions (Sunna) as well as the early experience of Muslims, she could have developed a scheme of rights and could have found, even in medieval Islamic literature, schemes of rights, though they might not be exactly what she would like to label schemes of human rights. [...] The scheme that medieval thinkers developed for derivative rights in Muslim societies may not be feasible today, especially as the moral and material contexts of rights have changed not only in Muslim societies but all over the world and among religions and cultures. Today's rights must reflect today's realities" (Moussalli 2003, 127, emphasis mine). Moussalli argues that the universalism of human rights must be shifted towards the foundational principles, while its normative expressions must remain adaptable and contextual. While many of the modern international human rights schemes can be claimed to be universal, as their principle overlaps with that of Islam and other cultures and religions, not all rights in modern human rights can claim that universality as they have a specific contextual trajectory in Western history (Moussalli 2003, 127-128).

Sachedina, similarly to Moussalli, is confronted by the cultural relativism of universal values as the terminology of application of these values in modern human rights discourse is experienced by Muslims as being alien imports. Sachedina therefore wants to search for the underlying foundations of these universals from within Islam: "Epistemological and ontological discussions about the foundations of human rights are divisive and controversial. Arguments for avoiding such controversial conversations, simply because they are unimportant for the development of human rights regimes, are defeatist. Without engaging those Muslim scholars and intellectuals who deny these universal principles and their cross-cultural application, these important values - which underlie the protection of human dignity and human agency in the context of universal human rights - will lack the necessary legitimacy and enforcement in the Muslim world. As long as the moral and metaphysical foundations of human rights norms remain unarticulated, they will be easily dismissed as yet another ploy to dominate Muslim societies by undermining their religiously based culture and value system" (Sachedina 2009, 5, emphasis mine).

As with Moussalli, Sachedina criticizes both the claim of hermeneutical universalism and the epistemological vacuum of modern human rights schemes. Both its secular and individualistic contents makes it untranslatable towards many cultures..$^{15}$ Also without articulated underlying foundations, there are

15 Although Sachedina views the UDHR as the main representative of human rights as it is the most philosophical worded texts of all modern human rights schemes. 
no hermeneutical bridges to be made (Sachedina 2009, 3-4, 7-9). Without overlapping foundational premises, any Islamization of knowledge, or rather Islamization of human rights, is doomed to fail.

TABLE 1 A Typology of 'Islam and human rights' discourse

\begin{tabular}{|c|c|c|c|}
\hline Author: & Human rights: & Islam: & Discourse: \\
\hline Baderin & $\begin{array}{l}\text { Modern international } \\
\text { human rights } \\
\text { law=universal }\end{array}$ & $\begin{array}{l}\text { Qur’ān- } \\
\text { Sunna=immutable, } \\
\text { Sharī'a=immutable, } \\
\text { Islamic substantive } \\
\text { law=dynamic, Islamic } \\
\text { legal theory=premises }\end{array}$ & Synthesis, compatibility \\
\hline Mayer & $\begin{array}{l}\text { Modern international } \\
\text { human rights } \\
\text { law=universal }\end{array}$ & $\begin{array}{l}\text { Islamic human rights } \\
\text { schemes=relative, } \\
\text { positive law and } \\
\text { constitutions of } \\
\text { Muslim-majority } \\
\text { countries=relative }\end{array}$ & $\begin{array}{l}\text { Compatibility, } \\
\text { Islamization of } \\
\text { knowledge }\end{array}$ \\
\hline Moussalli & $\begin{array}{l}\text { Western philosophical } \\
\text { premises=relative, } \\
\text { classical Islamic human } \\
\text { rights schemes and } \\
\text { schemes=relative, } \\
\text { modern international } \\
\text { human rights } \\
\text { law=relative }\end{array}$ & $\begin{array}{l}\text { Qur'ān- } \\
\text { Sunna=immutable, } \\
\text { Islamic substantive } \\
\text { law=dynamic, Islamic } \\
\text { legal theory=premises }\end{array}$ & $\begin{array}{l}\text { Inherent and unique } \\
\text { human rights traditions, } \\
\text { compatibility, } \\
\text { overlap philosophical } \\
\text { premises=universal, } \\
\text { Islamization of } \\
\text { knowledge }\end{array}$ \\
\hline Sachedina & $\begin{array}{l}\text { Modern international } \\
\text { human rights } \\
\text { law=relative, Western } \\
\text { philosophical } \\
\text { premises=semi-universal, } \\
\text { Islamic philosophical } \\
\text { premises=semi-universal }\end{array}$ & $\begin{array}{l}\text { Islamic legal theory } \\
=\text { premises, Islamic } \\
\text { theology=premises, } \\
\text { Islamic substantive } \\
\text { law=dynamic/relative }\end{array}$ & $\begin{array}{l}\text { Overlap philosophical } \\
\text { premises=universal, } \\
\text { compatibility }\end{array}$ \\
\hline
\end{tabular}


From our small analysis we notice several elements which can be used to construct a basic typology. Human rights is either represented by international human rights schemes such as the UDHR or the ICCPR, ${ }^{16}$ which are viewed as being either universal or culturally relative, or as having foundational premises which are grounded in Western thought, history and conflict but can overlap with the premises of other religions and cultures (thereby making all these premises relative by nature, whereby universalism is found in their overlaps). Islam is represented by its primary sources (Qur'ān, Sunna), substantive law (al-furū' al-fighiyya), theology and legal theory (ușül al-figh), and other conceptions of what defines Islamic law. It is this latter category which can be confusing as there are multiple configurations and categorizations which can be conflated in thin descriptive discourses on Islam and human rights such

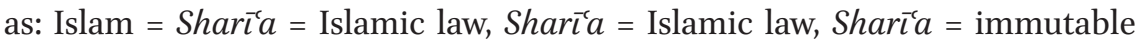
* substantive law, substantive law $=$ dynamic/relative $=$ Islamic law, Sharî $a=$ substantive law $=$ Islamic law, Islamic law $=$ Muslim-majority national law, and Islamic law = Islamic legal theory + applied substantive law. These categorizations and conflations are therefore important to take into account when providing a thick description and strategy for Islam and human rights discourse.

The overall majority of literature in relation to Islam and human rights states that a form of compatibility between Islam and modern human rights is possible, but many also believe that a true form of compatibility has not been attained yet. What is acknowledged is that Muslims have incorporated ('Islamization of human rights') and engaged with ('synthesis/compatibility') elements of modern human rights discourse. To determine an effective thick description and strategy it is therefore important to separate these into two distinct discourses: Islamic human rights discourse and 'Islam and human rights' discourse. Islamic human rights discourse is an internal discourse on human rights that is not pressured by external forces or ideologies. It is a discourse on Muslims' own terms. 'Islam and human rights' discourse on the other hand emerged together with the emergence of the modern human rights regimes, and has been a constant external pressure on Muslims to reform 'Islam(ic law)' and has created apologetic discourse $\mathrm{e}^{17}$ such as the Cairo Declaration on Human

16 The United Nations 'International Covenant on Civil and Political Rights' adopted in 1966.

17 The Cairo Declaration has Islamicized the UDHR, seeking a form of compatability that is more counterculture than reconciliation, but as it applies modern human rights law as 
Rights as upheld by United Nations' Muslim-majority body, the Organisation of Islamic Cooperation (OIC). ${ }^{18}$ The creation of such apologetic discourse is "merely the result of the efforts of mainstream religious communities to avoid the perception that they stand against the tide of international sentiment" (Bucar and Barnett 2005, 4). What our above typology has shown is that both forms of discourse exist, but they have yet to attain their desired level.

The question of universalism of either human rights or Islam itself, or which element of them can be called universal or not, is an important development which has generated the more mature responses by Baderin, Moussalli and Sachedina. Baderin shows that many elements of classical Islamic law can already be synthesized with modern human rights law. But where they conflict he, in general, provides apologetical solutions which are not deeply grounded in the Islamic tradition. Moussalli and Sachedina try to grapple with these conflicts by synthesizing Western and Islamic premises to create more grounded inherent criteria from within Islamic law to address these conflicts. And these need further development to become the criteria they desire them to be. But their critique of the relativism of modern human rights is an important step into reconciliation, as thereby both Islam(ic law) and human rights are approached as dynamic fields which can integrate into one another through a more organic and inherent process, instead of a process forced from without.

We therefore want to conclude with an assessment of how to proceed from here. To truly grapple with the question of Islam and human rights and reform and/or renewal, is first to truly define what is what, and what influences what. Technically, in today's globalism and international law regime, all cultures and states have to engage with both the foundational and applied aspects of human rights to maintain an internationally expected standard of peace, welfare, and justice. Human rights have become the universal language for society on what it means to be human. When it comes to human rights discourse, there are two fields which we need to distinguish (as they are often conflated):

its template it is also a form of apologetics. At the same time the Cairo Declaration can be compared to Pope John XxıII's 1963 apostolic writing, Pacem in Terris, which acknowledges and follows the human rights articles as drafted in the UDHR. Even with Pacem in Terris, Vatican II and the popes afterwards acknowledging modern human rights, the Vatican as a non-UN state still hasn't signed the 1948 UDHR or the 1966/1997 ICCPR, but has endorsed and supported them and other human rights declarations and conventions in the United Nations Human Rights Council. It declares it supports human rights as a moral force, not as a temporal force.

18 For the full declaration, see: "Cairo Declaration On Human Rights In Islam", Oic-Iphrc.Org, 2019, www.oic-iphrc.org/en/data/docs/legal_instruments/OIC_HRRIT/571230.pdf. 
1. Philosophy of law: meaning thereby world philosophy, which deals both with the metaphysical, moral, and practical reason side of what is a human (ontology/anthropology), what does a human need and deserve (claim rights), what must he do for others (duty rights). What rights can be determined as universal or relative generally revolves around the distinction between existential or core rights and cultural rights. ${ }^{19}$

2. Theoretical and positive law: in the form of international treaties, declarations and conventions, which provide frameworks for both national and international law, and are created in international political bodies in cooperative fashions. These represent universal standards of human treatment expressed in limited judicial 'bundles of consensus. ${ }^{20}$

When it comes to Islamic human rights discourse and 'Islam and human rights' discourse there are four fields we need to distinguish (especially as 2 and 3 are constantly conflated, and 1 is neglected):

1. Islamic philosophy of law or legal theory (ușül al-figh $)^{21}$

2. Islamic theoretical or substantive law (al-furū'al-fiqhiyya $)^{22}$

3. Muslim positive or national law and policy (qānūn/sìyassa $)^{23}$

4. Islamic international law (siyar $)^{24}$

To discuss Islamic human rights discourse in relation to all these fields that are related to Islamic law would go beyond the scope of this article, ${ }^{25}$ so we will focus on the most foundational one, Islamic legal theory. Although modern human rights law has tried as much to avoid the 'why' of human rights, it is impossible for a religious tradition to do the same (Bucar and Barnett 2005, 1-2). Religion's main concern is providing meaning, providing a 'why' for what is and what ought. If human rights claim both an is (what is the human?) and an ought (what must fundamentally be done or avoided?), it naturally enters

19 For a discussion on multicultural and multireligious philosophical foundations of human rights, see: Cruft et al 2015, 1-41; Monteiro 2014, 167-172, 199-202, 246-294, 327-349, 389419; Corradetti 2011; Runzo et al 2003.

20 For an overview of the treaties, conventions, and their positive law applications, see: Jayawickrama 2006.

21 We will discuss this field of Islamic law more in detail below.

22 For the development of figh, see: Akgündüz 2010, 109-179.

23 On premodern national law (qānūn), policy (siyāsa) and Islamic law, see: Akgündüz 2011, 105-606. Akgündüz 2010, 231-250. On modern national law and Islamic law, see: Emon 2012, 52-81; Akgündüz 2010, 251-355.

24 On siyar, see: Akgündüz 2011, 607-641; Bsoul 2008, 1-38; Moḥammed 2013, 125-147.

25 At IRTIS we are working on several projects concerning Islamic human rights discourse and how modern international law can be approached from a renewed approach to siyar. This includes creating contemporary figh commentaries (sharh) on modern human rights treaties and conventions. 
a field wherein a religion must see if and how it overlaps with its own $i s$ and ought (compatibility). This also includes the central question if its own $i s$ and ought has an internal rights discourse, meaning is human rights a new ethical hermeneutic (i.e. and therefore demands a hermeneutics of discontinuity), or is it an already existing one grounded in its tradition and source texts (i.e. a hermeneutics of continuity)? And can Islam contribute to the future of the modern international human rights regime (Bucar and Barnett 2005, 7)? So do Muslims have a philosophy of human rights within classical Islamic thought? As Moussalli stated, yes they have, meaning we should technically move beyond the basic compatibility discourse as Islam has its own internal rights discourse. But can this discourse be used to contribute to modern human rights discourse? On this, Moussalli is skeptical as he believes classical Islam's rights discourse was created within a different sociology. Khaled Abou El Fadl shares his skepticism by also stating that these classical right constructs were generally pragmatic and not philosophically coherent concepts (Abou El Fadl 2014, l-lii, 320-321).

These claims about both the sociological limitations and philosophical incoherence of classical Islamic human rights discourse has, according to my opinion, to do with the conflation of the rights discourses of Islamic substantive law and Islamic legal theory. The former applies the theoretical concepts of the latter in indeed a pragmatic and sociological fashion. And the latter has much more coherence and universalism than how it came to be used in Islamic substantive law. We will therefore conclude this assessment with a small synopsis of the classical Islamic philosophy of human rights, and what we can learn from this in relation to the other fields of Islamic law.

\section{5}

\section{The Classical Foundation of Islamic Human Rights Discourse}

The classical Islamic philosophy of human rights was developed within Islamic legal theory (ușül al-figh) as a duty-claim scheme, wherein a coherence was sought between what humans can claim as their right (such as a right to a certain property) and the duty of other humans to fulfill and protect that right (e.g. not to steal that property and to punish the thief who does steal it). These claim-rights were labeled haqq/huqūq al-ibād, human rights, ${ }^{26}$ and

26 Next to ḥaqq/ḥuqūq al-ibād also ḥaqq/ḥuqūq al-nās and ḥaqq/ḥuqūq al-ādamiyya was used. Creational rights were and sometimes subsumed under general rights of all creation (haqq/ḥuqūq al-makhlüqat). But human and creational rights were also generally subsumed under the term huqūq al-ibäd, rights of the servant, whereby servant here was 
these public duty-rights as haqq/huqūq al-ämm. But within Islamic theology, being a theistic religion, God is also viewed as having a personhood who can make claims on His creations (haqq/huqūq Allāh), ${ }^{27}$ and who performs duties towards them. Even though He neither needs His claim-rights, nor is $\mathrm{He}$ obliged to perform anything that is not grounded within His own nature (there can be no external duty on Him). This huqūq scheme represent both a rational heuristic as well as an Islamic natural rights regime which balances and upholds private and societal needs through the rule of law, by imposing duties on, and acknowledging claims by, individuals and governing authorities. ${ }^{28}$ This regime was constructed based on ontological and anthropological assumptions on what constitutes private and public interest (mașlaha /pl. mașāliḥ) ${ }^{29}$

Although there were some clear scriptural designations of what constitutes a divine or human right, the overall content and structure of the huqūq scheme was constructed through rational and dynamic intra-juristic discourses, and served as extra-scriptural indicators for determining general and specific wellbeing (mașlaha) (Emon 2004, 355-365; Emon 2006, 326-328, 390). Divine rights came to represent God's subjective claim rights in relation to creed and worship ('ibādāt) through which God makes a subjective claim on mankind to show "thankfulness to the benefactor (shukr al-mun'im)" as He created them and endowed them with reason and benefits (Vasalou 2008, 46; Al-Shāțibī 2011, 1:250; Al-Zuhaylī 2013, 1:154-155; Al-Dabūsī 2006, 437; Al-Taftāzānī 2013, 2:316-317). Next to these subjective claims there is a second category of divine rights which represent public interests which cannot be claimed by anyone in particular, they are rather one-sided public demands on the individual, as they are meant to rid the world of evil and corruption (ikhlä' al-'älam 'an al-fasād). Here God is used in an objective way to represent His creation in their general rights (haqq al-'āmm) and interests (mașāliḥ/nafa'al-'̄amm) such as in matters of penal law, public order and safety (hisba), infrastructure and markets, trust funds (awqāf), taxes (kharāj/ ushr), which all preserve the human necessities (which are subsumed under the universals/objectives of Islamic law, kulliyāt) maqāșid al-sharîa ) such as preserving life and access to wealth. Human rights are subjective private claims (haqq khäṣs ) preserving and representing individual interests (mașlaḥa khäșsalfard), such as rights of inviolability and presumption of innocence (ișma), freedom (ḥurriya), ownership (milkiyya),

understood as referring to the totality of mankind and creation, as all serve and worship $\operatorname{Him}(\mathrm{Q} 17: 44,22: 18,24: 41,30: 26,51: 56)$.

27 Although there are some occurrences of haqq/huqūq al-Rabb in some juristic works. Cf. Hallaq 2017, 11.

28 I have discussed this huqūq scheme also extensively in relation to the tafsīr tradition, see my upcoming chapter: Mol 2019.

For discussions on mașlaḥa, see: Opwis 2010; Al-Ābidīn Al-Nūr 2004. 
wealth $(m \bar{a} l)$, trade $(b u y \bar{u})$, access to water, possible forgiveness by victim's family/court, retaliation (qișasss), repentance, fair trial, punishing the slanderer (hadd al-qadhf), family and its maintenance (nafaqa), and inheritance (mirāth). Human rights are technically unlimited as they are defined as "every claim-rights other than divine claim-rights". Meaning what constitutes human rights is open-ended while divine rights are determined and close-ended. (AlZuḥaylī 2013, 1:154-157; Al-Zuhaylī 2008, 9:22-23; Al-Taftāzānī 2013, 2:318-322; Mullājiyūn 2017, 2:122-128; Emon 2006, 339; Hallaq 2017, 8-10; Akgündüz 2011, 23, 25; Nyazee 2016, 221; Al-Shāțibī 2011, 1:292-293).

The fact that God is self-sufficient (al-ghanī) means He is therefore transcendent above any need or want. This applies both to His subjective and representative rights, as they are called divine rights because the "initiative [for commanding these rights] comes from Him [which would imply] that God is benefitted by it, but the principle is that God is not in need (mustaghnī) of such" (Sanbihulī in Mullājiyūn 2017, 2:128). There is no divine right which does not incorporate creational benefit, nor is there no human right which does not serve Him (Hallaq 2017, 5-6). Therefore divine rights are based on leniency (almusāhala) (Al-Taftāzānī 2013, 2:371). This, of course, is not the same for human rights, on which human existence depends for survival and prosperity, which were therefore deemed necessary (wujūb), and its presence in the world to be viewed as that of scarcity (shuhh), paucity (di $q$ ), and that they are easily undermined (ḍanna) (Al-Rāzī 2012, 2:244; Al-Taftāzānī 2013, 1:421; Emon 2006, 378). It is this difference between creator and creation which was also projected unto the claims and duties linked to each ontology, creating a hierarchy of no-need (God) versus need (humanity) within the Islamic huqūq scheme. As expressed by Fakhr al-Dīn al-Rāzī (d. 606/1210) in his commentary on Q 1:4:

And it is known that the obligatory duties fall into two categories: divine rights and human rights. Divine rights are based on liberality (al-musāmaha) because the Exalted is in no need (ghanī) of creation (al'älamin), and human rights are those which necessitates reserved caution concerning them (yajib al-ihtirāz 'anhā).

AL-RĀZī 2009, 1:192

Human rights were seen as ontologically established within every born human, whether they are a child or insane, representing a natural rights scheme grounded within the divine covenant ('ahd), ${ }^{30}$ as expressed by the Hanafite Abū Bakr al-Sarakhsī (d. 49o/1097): 
As God the Exalted created humanity to carry out His trusts (amānatahu), ${ }^{31}$ He dignified them with reason $\left(b i-l_{-}^{-} a q l\right)$ and legal personhood (aldhimma) in order to be a people with legal capacity (ahlan) for the necessary rights God the Exalted has placed over them. Then He established for them inviolability (al-ișma), freedom (al-hurriyya), and property (al-mälikiyya) to continue carrying out their trusts. Hence, this [right of] freedom, sanctity, and property are granted to a person at the time they are born (hina yülad). Those capable of discernment (al-mumayyiz) and those not capable of discernment (ghayr al-mumayyiz) are equal (sawa') in this regard, so this applicable legal personality for the necessary rights (li-wujūb al-huqūq) is established at birth whether they are capable of discernment or not capable of discernment.

AL-SARAKHSĪ 2015, 2:334

The Islamic rights scheme envisioned natural (and revealed) rights and duties as grounded in a human ontology in which the human is rational, so he can know his rights and duties, and a legal personality (ahliyya/dhimma), so he can claim and fulfill his rights and duties. ${ }^{32} \mathrm{~A}$ dhimma is a repository of incorporeal rights who has "the capacity to be the subject of relations of huqūq—of acquiring claims over others and being the subject of claims in turn, of having rights and obligations" (Vasalou 2008, 154). This deontological human ontology, this Islamic humanum, ${ }^{33}$ was seen as universal, providing natural rights to all humans, whatever their age, background or mental state, whereby all humans (including unborn) are "people of necessity [in rights] (ahliyyat alwujūb)". And obligating all mature sane humans to fulfill those rights as in having responsibility (takliff) to fulfill them, termed "people of fulfillment [of rights] (ahliyyat al-adā)." ${ }^{34}$ As within such a safeguarding context people will have the chance to know and pursue God's personal rights.

These rationally known rights (ḩuqūq 'aqliyya) indicate a minimal deontology based on Islamic anthropological notions of human nature $(\text { fitra })^{35}$

31 Referring to the trusts mentioned in Q.33:72, which are understood to be the fulfillment of divine and human rights. Cf. Al-Qūnawī 2001, 15:430-435.

32 For similar statements on this Islamic rights scheme, see: Al-Dabūsī 2006, 432; Al-Taftāzānī 2013, 2:337; Senturk 2013, 290-311; Peters 1999, 5-14; Nyazee 2016, 221-233.

33 Humanum is a term, especially prominent in modern Catholic theology, to define the human from a deontological human rights perspective and is therefore, in my opinion, a fitting synonym for ahliyya/dhimma. Cf. O'Leary 2005, 49, 53.

34 For a full overview of figh discourses on ahliyya/dhimma, see: Al-Namla 2009, 1:208-220; Al-Zuhaylī 2013, 1:164-168; Arabi 2011; Akgündüz 2017, 52-82; Khazna 2012, 376. On fitra, see: Griffel 2012. 
divine rights (ḥuqūq Allāh)

fixed

subservient to human rights human rights (ḥuqūq al-'ibād)

open ended

dominant over divine rights

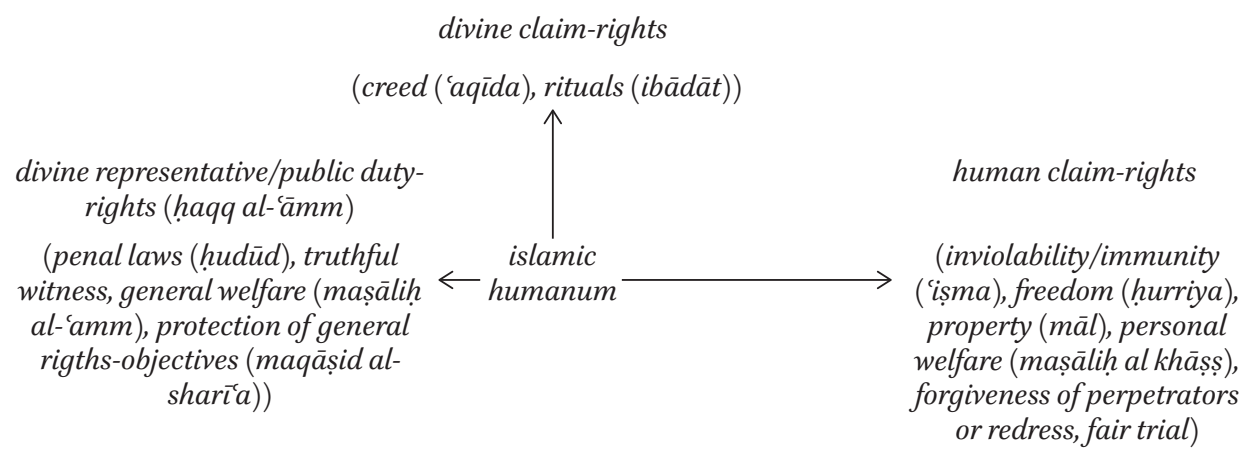

FIGURE 1 Islamic rights (huqūq) scheme

and necessary knowledge (wujūb al-nazar/ilm al-darūra), ${ }^{36}$ and provide a universal discourse and heuristic to construct rational and revealed duty-and claim-rights for natural (i.e., non-political) and institutional (i.e., political/rule of law) contexts. This classical human rights discourse was therefore uniquely both duty-and claim rights based, while the majority of classical Western philosophical and Christian discourse on ethics was focused on public duties upheld by the ruler and rarely saw the individual as a bearer of rights (Boot 2017, 1; Griffin 2013, 9-10). Although many elements of the Islamic huqūq scheme concerning divine rights overlap with classical Western discourse as a form of public duties upheld by the ruler, the Islamic scheme also clearly viewed the individual as a bearer of human rights which were deemed as being dominant over divine rights. This emphasis on human rights became only possible in Western thought after it had a paradigm shift away from the concept of divine rights of kings, while such a collapse of absolute monarchy and divine rights was unknown to Islam (Hallaq 2017, 17-18, 20-21, 25-27; Boot 2017, 2-3).

During the early Enlightenment the divine rights of kings shifted towards an international natural law of state rights, whereby it took several more centuries for personal rights concepts to develop beyond nationalistic frameworks (i.e. bill of rights and constitutions) into the full universalistic personal rights schemes of modern international human rights law serving as a central standard for national law regimes (Evans 2007, 3-4). It can therefore be argued non-apologetically, as Peters emphasizes, that "Islam promotes or

36 On “necessary knowledge", see: Abrahamov 1993, 20-32. 
enjoins these positively valued concepts to the same extent or even more than 'Western culture' or Christianity and that it has done so for a much longer period" (Peters 1999, 5). Based on Islam's classical philosophy and theory of law we can provide a very broad and well grounded human rights discourse, an Islamic human rights discourse, which can be labelled as an Islamic science of human rights ('ilm al-huqūq). But even though a hermeneutics of continuity between Islam and human rights discourse can be established, there is still much to be explored why both non-Muslims and Muslims themselves have seemingly neglected this intellectual tradition and work from a hermeneutics of discontinuity. ${ }^{37}$

\section{Islamic Human Rights Discourse and Hermeneutics of Continuity}

From the typology discussed above it was also determined that a satisfying compatibility/synthesis within the different fields of and related to Islamic law has not been achieved yet. If we then re-assess our four fields, which determine Islam and human rights discourse, based on the Islamic science of human rights, we can review each field based on what effective approach is required. We can distinguish these in classical Islamic hermeneutical approaches which we will re-adapt in service of our hermeneutics of continuity: independent reasoning or reinterpretation $(i j t i h \bar{a} d)$ in relation to renewal (tajdīd), reform (ișlāh $)$ or correction (tașhịh). Renewal refers to reviving or re-centering a science or approach within Islamic thought. Classically, it means renewal of Islam's guidance, explanation of its truth, and the expulsion of heresy and extremism, but also aligning the religion with people's benefits, societal traditions and the norms of civilization as a sudden rediscovery of the hermeneutics of continuity. Within Islamic modernism it is mainly used to express a synthesis of tradition (i.e., Islam) with modernity in all its aspects. Reform on the other hand

37 Many works on Islam and human rights either engage Islam with modern human rights conventions as the determining criteria, or engage human rights from modern concepts of the objectives of the Sharīa (maqūsid al-sharīa). Only a handful use the classical huqūq Allah wa huqūq al-ibād scheme as the determining criteria to engage either. For a discussion on the latter, see: Al-Khatib $(2013,27-48)$ who demonstrated that human rights in the Islamic tradition is a system based on ḥuqūq Allah, ḥuqūq al-iibād and ḥuqūq mushtaraka (shared rights between God and people). He explained that this system of rights is to be found in different branches of figh literature including legal theory (ușül al-fiqh), substantive law (furū ), legal maxims ( $\left.q a w \bar{a}{ }^{c} i d\right)$, similarities and distinctions (ashbāh wa furūq), legal objectives (maqāṣid), islamic political rulings (siyāsa shar'iyya), as well as Islamic legal rulings on buildings (ahkām al-bunyān). He also stressed that the implementation of this system is placed in the literature on history, travels (rihlāt), and endowment (waqf). 
has both a traditional meaning of personal or societal reform towards goodness and piety, and a modern meaning which deconstructs and reconstructs the Islamic sciences and their contents to adapt to modernity (i.e. mixing a hermeneutics of discontinuity and continuity). (Kamali 2018, 485, 493-494.) Correction is a natural process which has taken place within the schools of law (madhăhīb) over the centuries, and has much in common with renewal, as a continued application of a hermeneutics of continuity: "[J]urists who had modified 'the earliest doctrines due to the difference in time or to changing conditions of society' [as] the questioner's circumstances need to be taken into consideration and changing conditions justify changing certain rules in order to bring them into conformity with the needs of the society in question. [Khayr al-Dīn] al-Ramlī [(d. 1082/1671)], when referring to this procedure, states that the texts have been altered; in fact he states in stronger terms that they are 'corrected (sahhaha) by the main jurists of the School due to changing times or the changes of the conditions of the people.' 38 This method of 'correction' became known as tașhịh" (Mohammed 2013, 58).

So when assessing each field in relation to renewal, reform and correction, we can attain a better understanding what is needed in which field, and how to categorize the works written into those fields in relation to Islam and human rights:

1. Renewal (tajdīd) of Islamic legal theory (ușül al-figh): Is reform needed for the analyzed Islamic philosophy or science of human rights to reassess its metaphysical underpinnings? Our analysis above shows it provides a universal and comprehensive concept of humans as right-bearers, and sees human rights as both dominant over religious creedal obligations and as open-ended, meaning they can be extended indefinitely in a coherent fashion. No reform, or a hermeneutics of discontinuity, is therefore needed. But there is a lack of an Islamic philosophical engagement of modern human rights philosophy, it must therefore undergo a renewal

38 This changing of the rulings based on the changing of the times is a central maxim within Islamic legal theory, especially among the Hanafìs: "The legal cases are either established on the basis of a direct text [...] or on the basis of $i j t i h \bar{a} d$ and juristic reasoning $(r \bar{a} y)$. In most of the cases the jurist develops his legal arguments and judgments on the basis of the social convention ('urf) of his time such that if he was living in a different time he would make a different legal ruling. It is precisely for this reason that they [i.e., classical scholars] said, while discussing the conditions and qualifications required in ijtihād, that he must be well-versed in the local customs and habits of the people. Therefore, many laws change according to changing times (al-ahkām takhtalif bi-ikhtilāf al-zamān) such that if a law was allowed to remain the same as it was in the first case this would cause great difficulty and harm to the people (al-mashaqqa wa al-darar), and this would be a violation of the universal principles of the Sharita which are based on the need to make things light and easy (takhfíf wa taysīr)" (Ibn ‘Ābidīn 1930, 2:125). 
in how it engages other philosophical traditions to establish a more clear hermeneutic of continuity. The ilm al-huqūq must be reactivated to engage the world, as it has much to contribute in how it grounds human sanctity and reasoning within a pluralistic world. But more importantly it provides an authentic, non-apologetic ground to develop an internal Islamic human rights discourse, and an Islamic assessment methodology in how construct, compare and apply human rights.

2. Correction (tașhīh) of substantive law (al-furū'al-fiqhiyya): Islamic substantive law integrated the Islamic rights discourse from the start and developed the concept of rights into a full rights scheme within its theoretical and practical law. It was comprehensive in claim-rights (as it projected these rights unto all humans, Muslims and non-Muslims), but was constricted in several areas of duty-rights (Islamic substantive law did not determine certain elements of religious minority (millet) law and application as this was determined by the minority groups themselves) (Emon 2014, 43-44). Islamic substantive law was a true theoretical judges' law and was for the majority non-political (as it was not constructed by political agents). But it was also a highly sociological enterprise, confined by its times. So does Islamic substantive law need to re-asses its rights scheme? Yes, a re-assessment is needed, as it constructed its rights scheme in relation to pre-modern social realities (a point which Moussalli mentioned). Technically it is national law which is in interrelation with modern human rights law, Islamic substantive law is not. But as national law bases much of its identity on its discursive nature with Islamic substantive law, it is Islamic substantive law which must determine if, and in what way, modern human rights law can be a theoretical source (as a form of social convention ('urf)), and how it wants to impact national law as its theoretical advisory foundation. The way Islamic substantive law informed the legal implementations in the pre-colonial era, it must inform national law in the modern era. The main problem is that Islamic substantive law in modern times has become politicized in the form of identity politics and counterculture, ${ }^{39}$ and has struggled in finding its balance between tradition and modernity. Islamic substantive law must renew its non-political nature, and correct its rights scheme to current sociological realities and times by using its internal hermeneutic of tashịh and provide a vision of continuity between past and present. ${ }^{40}$

39 Being used in Islamism as a top-down authority, while it has always been a bottom-up authority. For a discussion on this, see: Mol 2017, 953-954.

40 Although there exist many hundreds, if not thousands of modern figh works, they lack a coherence in which human standards they uphold. Although the modern maqāṣid 
3. Reform (ișlāhn) of national law and policy (qūnūn/siyāsa): We must first of all emphasize that Muslim-majority national law is not Islamic law, it is qānūn as it is political, and must be labelled as civil law even if it claims a grounding within the Islamic sources and legal tradition. Much of national law should technically be in a constant state of reform, discontinuing outdated or unworkable elements of law established by previous political lawmakers, and creating new laws aligned both with the nation's needs and new standards of international law. Classically, legal implementations integrated the Islamic rights scheme created within Islamic substantive law in a positive law fashion and is, just as modern national law, both comprehensive in scope in determining claim-rights and duty-rights for all its citizens. When national law replaced the classical legal implementations it mainly applies a mix of pre-and post-colonial law, while codifying certain aspects of substantive law in a way which deformed it. ${ }^{41}$ Any national law must be acceptable to both national and international standards. For Muslims to accept its Muslim-majority law, or any national law, is to determine its acceptability from both an Islamic and international law perspective. Adherence to human rights standards, both Islamic and international standards, converge into a criteria to which national law is judged. Elements of Muslim-majority national law which desire to apply Islamic substantive law constructs, such as in family law, must not try to codify a 'thin description' of the Islamic substantive law tradition as a form of identity politics, but instead only use 'corrected' theoretical Islamic substantive law as an advisory foundation.

4. Correction (tașhịh) of Islamic international law (siyar): Modern international law needs to be re-assessed and re-engaged both from a Islamic philosophical perspective, and from a siyar perspective which both needs to search for compatibility and synthesis, as siyar has much positive input to give to modern international law (such as its high regard for non-combatant lives, ${ }^{42}$ and its arguments for restricting weapons of mass-destruction ${ }^{43}$ ). Siyar was a pragmatic and sociologically legal field within Islamic substantive law, and therefore requires a 'correction' to

movement has tried to create new standards, it remains generally stuck on an hermeneutical level as the maqāṣid do not provide an ontology. On classical and modern maqāṣid discourse, see: Auda 2010.

41 For a discussion on this, see: Emon 2016, 275-309.

42 "Algase points out that the Islamic law of war "strikes a balance between military necessity and respect for human life in a manner which gives a higher priority to saving the lives of non-combatants than does modern international law." Al-Dawoody 2015, 36 fn18. For a discussion on this, see: Gasimov 2014, 81-92. For an example, see: Dar Al-Ifta Al Misriyyah 2009. 
modern social realities. Modern human rights declarations and conventions need to be reviewed to provide criteria for how siyar can apply an inward tașhịh (i.e. hermeneutics of continuity), whereby modern human rights law are viewed from the classical siyar concept of treaties (mu'āhadāt) which affect the national laws of nations bound by those treaties. As well as how siyar can provide an outward tașhị in how the world formulates declarations and conventions, whereby siyar represents Islam from a cultural hermeneutic which international human rights discourse must take into account. ${ }^{44}$ The 'ilm al-ḥuqūq provides in this way an authentic Islamic hermeneutics of international law, and can advise and guide Muslim diplomats when engaging in international councils and political bodies. In this way, siyar can serve as the international hermeneutic used to reform national law, based on both inward human rights discourse (i.e., Islamic human rights discourse) and external human rights discourse (i.e., 'Islam and human rights' discourse) by determining what is universal and what is relative in relation to conforming to international law.

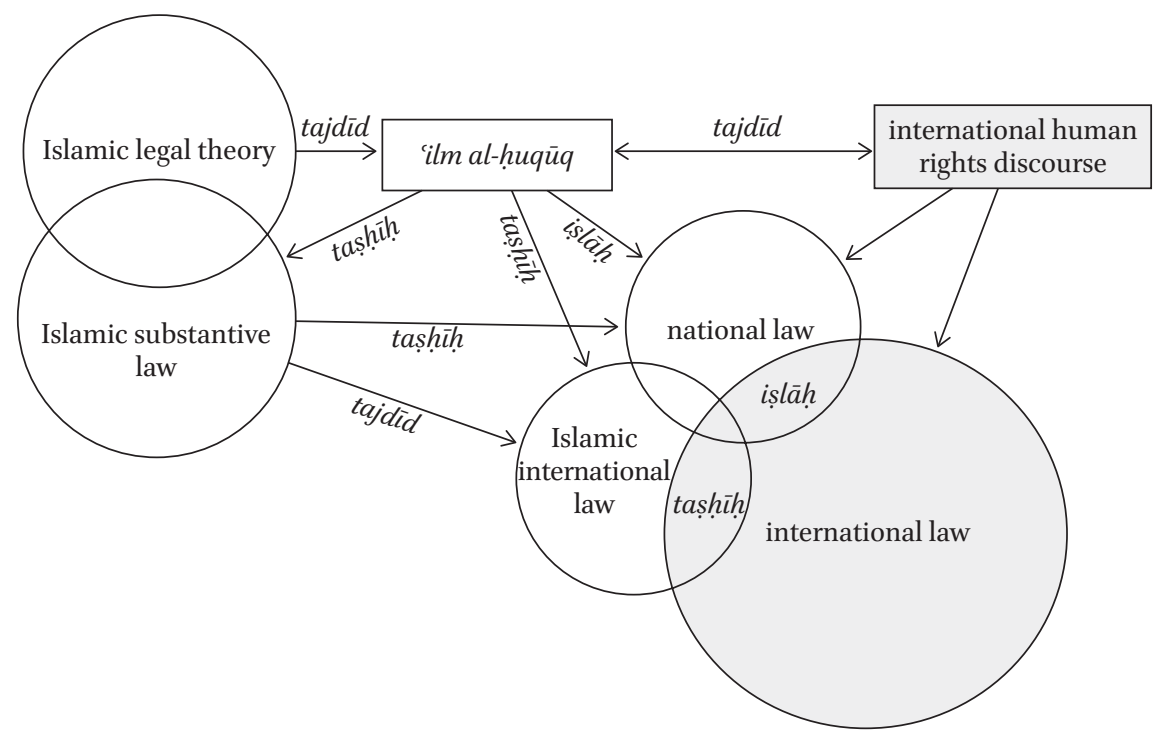

FIGURE 2 Islamic science of human rights and international human rights discourse

44 For fascinating examples, see: Shoukri 2011; El-Dakkak 2000. 
Through the typology we determined there is an acknowledgement that Muslims have incorporated ('Islamization of human rights') and engaged ('synthesis/compatibility') elements of modern human rights discourse, and that therefore both Islamic human rights discourse and 'Islam and human rights' discourse exist. But as they seemingly work from a hermeneutic of discontinuity both discourses have not attained the level that is desired. 'Islam and human rights' discourse emerged together with the emergence of the modern human rights regimes, and has for the majority generated apologetic or counterculture discourses. As stated by Recep Senturk: "I term this state of the Muslim world "human rights dependency on the West," by which I mean positioning oneself as the receiver or the opponent of the human rights discourse without making any contribution or offering an alternative to it. In their approach to human rights there are two groups of Muslim intellectuals. One group accepts and employs the present human rights discourse yet without contributing to it. The other group rejects the present human rights discourse but without formulating a viable alternative to it. I think it is high time for Muslims to make a dialogical contribution to the current human rights discourse in the world instead of simply accepting or rejecting it. In my opinion, the only way for Muslims to criticize and contribute to the present human rights discourse is to firmly ground their approach in the universalist legal tradition in Islam" (Senturk 2013, 308-309).

Before there can be a viable 'Islam and human rights' discourse, first there needs to be a renewal of the Islamic philosophy of human rights, as an authentic Islamic science of human rights ('ilm al-h̆uqūq), to formulate an Islamic human rights discourse which provides a hermeneutics of continuity between Islam and modern human rights. Hopefully, from the above assessment we can derive new understandings how to engage Islamic ethics in the form of a modern Islamic human rights discourse which is not reduced to a form of apologetics or mistaken conflations, but an internal discourse of human standards with which to reassess all fields of Islamic law and modern international law which overcomes both apologetics and othering.

\section{Bibliography}

Abiad, Nisrine. 2008. Sharia, Muslim States and International Human Rights Treaty Obligations: A Comparative Study. London: British Institute of International and Comparative Law. 
Abou El Fadl, Khaled. 2014. Reasoning with God: Reclaiming Sharíah in the Modern Age. London: Rowman and Littlefield.

Abrahamov, Binyamin. 1993. "Necessary Knowledge In Islamic Theology." British Journal of Middle Eastern Studies 20: 20-32.

Acevedo, G. A. 2008. "Islamic Fatalism and the Clash of Civilizations: An Appraisal of a Contentious and Dubious Theory." Social Forces 86: 1711-1752.

Adib-Moghaddam, Arshin. 2014. A Metahistory of the Clash of Civilisations. New York: Oxford University Press.

Akgündüz, Ahmed. 2010. Introduction to Islamic Law. Rotterdam: IUR Press.

Akgündüz, Ahmed. 2011. Islamic Public Law. Rotterdam: IU Press.

Akgündüz, Ahmed. 2017. Islamic Private Law. Rotterdam: IU R Press.

Al-Braizat, Fares. 2002. "Muslims And Democracy An Empirical Critique Of Fukuyama's Culturalist Approach." International Journal Of Comparative Sociology 43: 269-299.

Al-Dabūsī, Abū Zayd. 2006. Taqwìm al-Adilla fì Ușūl al-Fiqh. Beirut: Al-Maktaba al-'Așriyya.

Al-Dawoody, Ahmed. 2015. "Al-Sarakhsī's Contribution to the Islamic Law of War." UCLA Journal of Islamic and Near Eastern Law, Vol.14.

Al-Jabri, Mohammed Abed. 2008. Democracy, Human Rights and Law in Islamic Thought. London: I.B. Tauris.

Al-Khațīb, Mu'tazz. 2013. "Manẓūmat al-Ḥuqūq wa-Maqāṣid al-Sharīca 'inda alFuqahā'." Al-Tafāhum 39: 27-48.

Al-Marzouqi, Ibrahim Abdulla. 2000. Human Rights in Islamic Law. Abu Dhabi: n.p.

Al-Nabarāwī, Khadīja. 2008. Mawsū'at Ḥuqūq al-Insān fì al-Istām, 6 vols. Cairo: Dār al-Salām.

Al-Namla, 'Abd al-Karīm b. 'Alī. 2009. Al-Shāmil fì Hudūd Ta'rīfāt Muștalahāat 'ilm Ușūl al-Figh. Riyad: Maktabat al-Rushd.

Al-Nūr, Zayn al-'Ābidīn. 2004. Rāyy al-Ușūliyyìn fí al-Mașālị̣ al-Mursala wa-al-Istị̣sān. Abu Dhabi: Dār al-Buhūth li-l-Dirāsāt al-Islāmiyya wa-Iḥyā̄ al-Turāth.

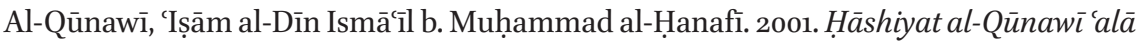
Tafsīr al-Imām al-Bayḍ̄wwī. Beirut: Dār al-Kutub al-'Ilmiyya.

Al-Rāzī, Fakhr al-Dīn. 2009. Al-Tafsīr al-Kabìr aw Mafātīh al-Ghayb. 1st ed. Beirut: Dār al-Kutub al-'Ilmiyya.

Al-Rāzī, Fakhr al-Dīn. 2012. Al-Mahșūl fì 'ilm Ușūl al-Fiqh. Damascus: Mu’assasat al-Risāla.

Al-Sarakhsī, Abū Bakr. 2015. Ușūl al-Sarakhsī. Beirut: Dār al-Kutub al-'Ilmiyya.

Al-Shāṭibī, Ibū Ishāāq. 2011. Al-Muwāfaqāt fì Ușūl al-Sharīa. Mansoura: Dār al-Ghadd al-Jadīd.

Al-Taftāzānī, Sa'd al-Dīn. 2013. Sharh al-Talwīh 'alā al-Tawdịḥ li-Matn al-Tanqūh. Beirut: Dār al-Kutub al-'Ilmiyya. 
Al-Ṭāḥūn, Rifaca Muhammad Mursī. 2013. Mawsū'at Ḥuqūq al-Insān fì al-Islām, 6 vols. Cairo: Dār al-Nawādir.

Al-Zuhaylī, Wahba. 2008. Al-Fiqh al-Islāmī wa-Adillatuh. Damascus: Dār al-Fikr.

Al-Zuhaylī, Wahba. 2013. Ușūl al-Fiqh al-Islāmī. Damascus: Dār al-Fikr.

Arabi, Oussama. 2011. "Legal Capacity." Encyclopaedia Of Islam, Three. Leiden: Brill.

Ardiç, Nurullah. 2012. Islam and the Politics of Secularism: The Abolition of the Caliphate (1908-1924). Abingdon: Routledge.

Auda, Jasser. 2007. Maqāṣid al-Sharīah as Philosophy of Islamic Law: A Systems Approach. London: International Institute of Islamic Thought.

Aysha, Emad El-Dīn. 2003. "Samuel Huntington And The Geopolitics Of American Identity: The Function Of Foreign Policy In America's Domestic Clash Of Civilizations." International Studies Perspectives 4: 113-132.

Baderin, Mashood A. 2008. International Law and Islamic Law. Aldershot: Ashgate Publishing.

Bin Bayyah, 'Abd Allāh. 2006. Hìwār 'an bu'd Hawla Huqūq al-Insān fì al-Islām. Riyad: 'Ubaykān.

Boot, Eric R. 2017. Human Duties and the Limits of Human Rights Discourse. Cham: Springer.

Breau, Susan C, and Javaid Rehman. 2007. Religion, Human Rights and International Law: A Critical Examination of Islamic State Practices. Leiden: Martinus Nijhoff Publishers.

Brons, Lajos. 2015. "Othering, an Analysis”. Transcience, Vol. 6, Issue 1.

Bsoul, Labeeb Ahmed. 2008. International Treaties (Mu'āhadāt) in Islam: Theory and Practice in the Light of Islamic International Law (Siyar) according to Orthodox Schools. 1st ed. Lanham: University Press of America.

Bucar, Elizabeth M. 2005. Does Human Rights Need God?. Grand Rapids, MI: Eerdmans, William B. Publishing Company.

Bucar, Elizabeth M., and Barbra Barnett. 2005. "The "Why" Of Human Rights." In Does Human Rights Need God?. Cambridge: Eerdmans.

"Cairo Declaration On Human Rights In Islam". Oic-Iphrc.Org, 2019. www.oic-iphrc.org/ en/data/docs/legal_instruments/OIC_HRRIT/571230.pdf.

Cavanaugh, William T. 2009. The Myth Of Religious Violence: Secular Ideology and the Roots of Modern Conflict. New York: Oxford University Press.

Corradetti, Claudio. 2012. Philosophical Dimensions of Human Rights. Dordrecht: Springer.

Cruft, Rowan, S. Matthew Liao, and Massimo Renzo. 2015. "The Philosophical Foundations Of Human Rights: An Overview." In The Philosophical Foundations of Human Rights. Ed. Rowan Cruft, S. Matthew Liao and Massimo Renzo. Oxford: Oxford University Press. 
Cruft, Rowan, S. Matthew Liao, and Massimo Renzo. 2015. Philosophical Foundations of Human Rights. Oxford: Oxford University Press.

Dar Al-Ifta Al Misriyyah. 2009. "Fatawa-Weapons of Mass Destruction." http:// dar-alifta.org/Foreign/ViewFatwa.aspx?ID=646.

Davison, Roderic H. 1973. Reform in the Ottoman Empire, 1856-1876. New York: Gordian Press.

Dzilo, Hasan. 2012. "The Concept Of 'Islamization Of Knowledge' And Its Philosophical Implications." Islam and Christian-Muslim Relations 23: 247-256.

Echr.Coe.Int, 2019. www.echr.coe.int/Documents/Annual_report_2003_ENG.pdf.

El-Dakkak, M. Shokry. 200o. State's Crimes against Humanity: Genocide, Deportation and Torture. Kuala Lumpur: A.S. Noordeen.

Emon, Anver M. 2004. “Natural Law And Natural Rights In Islamic Law.” Journal of Law and Religion 20:351.

Emon, Anver M. 2006. "Huqūq Allāh and Huqūq al-Tbād: A Legal Heuristic for a Natural Rights Scheme." Islamic Law and Society 13.

Emon, Anver M. 2012. "Sharīah And The Modern State." In Islamic Law and International Human Rights Law, edited by Anver M. Emon, Mark S. Ellis and Benjamin Glahn, 52-81. Oxford: Oxford University Press.

Emon, Anver M. 2014. Religious Pluralism and Islamic Law. 1st ed. Oxford: Oxford Univ. Press.

Emon, Anver M. 2016. "Codification And Islamic Law: The Ideology Behind A Tragic Narrative." Middle East Law and Governance 8: 275-309.

Evans, Malcolm D. 2007. "Does God Believe in Human Rights? A Reflection." In Does God Believe in Human Rights? Essays on Religion and Human Rights, edited by Nazila Ghanea, Alan Stephens, and Raphael Walden. Leiden: Martinus Nijhof Publishers.

Gasimov, Kamal. 2014. "Weapons of Mass Destruction in Muslim Fatwas." Security Index: A Russian Journal on International Security 20: 81-92.

Griffel, Frank. 2012. "Al-Ghazālī's Use of "Original Human Disposition" (fitra) and its Background in the Teachings of Al-Fārābī and Avicenna." The Muslim World 102.

Griffin, James. 2013. On Human Rights. Oxford: Oxford University Press.

Grote, Rainer, and Tilmann J. Röder. 2012. Constitutionalism in Islamic Countries. New York: Oxford University Press.

Hallaq, Wael. 2017. “God Cannot Be Harmed': On Huqūq Allāh/Huqūq al-Tbād Continuum." Draft Article. www.academia.edu/26412704/_God_Cannot_be_Harmed_ On_\%E1\%B8\%A4uq\%C5\%ABq_All\%C4\%81h_\%E1\%B8\%A4uq\%C5\%ABq_al$\mathrm{Ib} \% \mathrm{C} 4 \% 81 \mathrm{~d}$ _Continuum. This draft article was later published in: 2019. Routledge Handbook of Islamic Law, edited by Khaled Abou El Fadl, Ahmad Atif Ahmad, Said Fares Hassan. Abingdon, Routledge.

Ibn 'Ābidīn, Muḥammad Amīn. 1930. Majmūáat Rasāil Ibn 'Ābidīn. Istanbul: No publisher. 
Jayawickrama, Nihal. 2006. The Judicial Application of Human Rights Law: National, Regional and International Jurisprudence. Cambridge: Cambridge University Press.

Kamali, Mohammad Hashim. 1997. Freedom of Expression in Islam. United Kingdom: The Islamic Texts Society.

Kamali, Mohammad Hashim. 2002a. Freedom, Equality and Justice in Islam. Cambridge: The Islamic Texts Society.

Kamali, Mohammad Hashim. 2002b.The Dignity of Man: An Islamic Perspective. Cambridge: The Islamic Texts Society, 2002.

Kamali, Mohammad Hashim. 2007. The Right to Life, Security, Privacy and Ownership in Islam (Fundamental Rights And Liberties In Islam Series). Islamic Texts Society.

Kamali, Mohammad Hashim. 2011a. Citizenship and Accountability of Government: An Islamic Perspective. United Kingdom: The Islamic Texts Society.

Kamali, Mohammad Hashim. 2011b. The Right to Education, Work and Welfare in Islam. United Kingdom: The Islamic Texts Society.

Kamali, Mohammad Hashim. 2018. Tajdid, Islah and Civilisational Renewal in Islam. Malaysia: IAIs.

Kamali, Mohammad H. 1993. "Fundamental Rights Of The Individual: An Analysis of Haqq (Right) in Islamic Law." American Journal Of Islamic Social Sciences 10:340-366.

Khazna, Haytham 'Abd al-Hamīd. 2012. Tațawwur al-fikr al-uṣūlī al-Hanafí. Beirut: Dār al-Kutub al-'Ilmiyya.

Koçak, Mustafa. 2010. "Islam and National Law in Turkey." In Sharia Incorporated. Leiden: Leiden University Press.

MacQueen, Benjamin, and Shahram Akbarzadeh. 2010. Islam and Human Rights in Practice: Perspectives across the Ummah. Abingdon, Oxfordshire: Routledge, Taylor \& Francis.

Martens, Kurt Martens. 2009. "Dignitatis Humanae: A Hermeneutic Perspective on Religious Freedom as Interpreted by the Roman Catholic Church." In Hermeneutics, Scriptual Politics, and Human Rights: Between Text and Context, edited by Bas Gaay de Fortman, Kurt Martens, and M. A. Mohamed Șāliḥ. New York: Palgrave MacMillan.

Masud, Muhammad Khalid. 2019. "Clearing Ground: Commentary to 'Shari'a and the Modern State." In Islamic Law and International Human Rights Law: Search for Common Ground. Oxford: Oxford University Press.

Mayer, Ann Elizabeth. 2007. Islam and Human Rights: Tradition and Politics. Boulder: Westview Press.

Mohammed, Amjad M. 2013. Muslims in Non-Muslim Lands: A Legal Study with Applications. Cambridge: The Islamic Texts Society.

Mol, Arnold Yasin. 2017. "Rise Of Islamism, Extremism, And Islamic Counter Responses." In Great Events in Religion: An Encyclopedia of Pivotal Events in Religious History. USA: ABC-CLIO. 
Mol, Arnold Yasin. 2019. "Divine respite in the Ottoman tafsir tradition: Reconciling exegetical approaches to Q.11:117." In Osmanlida ilm-i-tefsir, edited by Murtaza Bedir et al. Istanbul: ISAR. Forthcoming.

Monteiro, Agostinho Reis. 2014. Ethics of Human Rights. Cham, Heidelberg: Springer.

Moussalli, Ahmad. 2003. The Islamic Quest for Democracy, Pluralism, and Human Rights. Gainesville: University Press of Florida.

Moyn, Samuel Moyn. 2015. Christian Human Rights. Pennsylvania: University of Pennsylvania Press.

Mullājiyūn al-Ḥanafī, Aḥmad b. Abū Saīid. 2017. Nūr al-Anwār Sharh Risālat al-Manār. Karachi: Maktabat al-Bushrā.

Nyazee, Imran Ahsan Khan. 2016. Islamic Legal Maxims (Qawā id Fiqhiyyah). Islamabad: Center for Excellence in Research.

O'Leary, David M. 2005. A Study of Josef Fuchs'Writings on Human Nature and Morality. Lanham, MD: University Press of America.

Opwis, Felicitas. 2010. Mașlaha and the Purpose Of The Law. Leiden: Brill.

Otto, Jan Michiel. 2010. Sharia Incorporated: A Comparative Overview of the Legal Systems of Twelve Muslim Countries in Past and Present. Leiden: Leiden University Press.

Peters, Ruud. 1999. "Islamic Law and Human Rights: A Contribution to an ongoing Debate." Islam And Christian -Muslim Relations 10: 5-14.

Roder, Tilmann J., and Rainer Grote. 2011. Constitutionalism in Islamic Countries: Between Upheaval and Continuity. New York: Oxford University Press, UsA.

Rubin, Avi. 2006. Ottoman Modernity: The Nizamiye Courts in the Late Nineteenth Century. Basingstoke: Palgrave Macmillan.

Runzo, Joseph, Nancy M. Martin, and Arvind Sharma Eds. 2003. Human Rights and Responsibilities in the World Religions. Oxford: Oneworld.

Sachedina, Abdulaziz Abdulhussein. 2009. Islam and the Challenge of Human Rights. New York, NY: Oxford University Press.

Saeed, Abdullah. 2012. Islam and Human Rights. United Kingdom: Edward Elgar Publishing.

Senturk, Recep. 2013. "Human Rights in Islamic Jurisprudence: Why should all Human Beings be inviolable?" In The Future of Religious Freedom: Global Challenges, edited by Allen D. Hertzke. New York: Oxford University Press.

Stibora, Carrie Rose. 2013. "Jacques Maritain and Alasdair Macintyre on Human Rights." The Catholic University of America.

Treaties.Un.Org, 2019. https://treaties.un.org/doc/publication/unts/volume\%20999/ volume-999-i-14668-english.pdf.

Vasalou, Sophia. 2008. Moral Agents and their Deserts: The Character of Mutazilite Ethics. 1st ed. Princeton University Press. 